\title{
Drawing the Boundaries of Mens Rea in the Jurisprudence of the International Criminal Tribunal for the Former Yugoslavia*
}

\author{
MOHAMED ELEWA BADAR**
}

\begin{abstract}
Even though more than a decade has passed since the creation of the International Criminal Tribunal for the Former Yugoslavia, the law of the most fundamental concept in international criminal law - mens rea - remains unsettled. Through its jurisprudence, the Yugoslavia Tribunal has made enormous efforts to assign different degrees of mens rea for different categories of crimes under its Statute. The present study is an attempt to clarify several issues with regard to the law of mens rea as developed in the case law of the Yugoslavia Tribunal. Among these issues are the following: what precisely is to be understood by the terms "specific intent", "special intent", "dolus specialis", or "surplus intent"? Similarly, what are the precise meanings of the terms "deliberately", "intention", "intent", "intentionally", "wilful or wilfully", "knowledge", and "wanton" as provided for in the ICTY Statute or as employed by the Chambers within its judgments.
\end{abstract}

\section{Contents}

1. Introduction 314

2. Special Intent or Primary Purpose Crimes 317

2.1. Terror Against the Civilian Population 317

2.2. Torture 320

2.3. Persecution as a Crime Against Humanity 322

2.4. Genocide 326

3. Direct and Indirect Intent Crimes 328

3.1. Rape - Direct Intent Crime 328

* The present study is a part of the author's PhD thesis entitled 'The Concept of Mens Rea in International Criminal Law - The Case for A Unified Approach'. The first part of the survey entitled 'Mens Rea - Mistake of Law \& Mistake of Fact in German Criminal Law: A Survey for International Criminal Tribunals', appears at 5 International Criminal Law Review (2005) 203-246.

** Judge, Ministry of Justice, Egypt; Former Senior Prosecutor, Public Prosecution Office, Egypt. PhD candidate in International Criminal Law, National University of Ireland, Galway (2002-2006); LL.M., NUI, Galway, (2001); LL.B. \& Bachelor of Police Sciences, Police Academy, Police College, Cairo, 1991. [elewa2000@hotmail.com] 
3.2. Outrages Upon Personal Dignity - Direct Intent Crime

3.3. Extermination - dolus directus or dolus eventualis

4. Wilful Crimes

4.1. Wilful killing

4.2. Wilfully Causing Great Suffering or Serious Injury to Body or Health

4.3. Destruction or Wilful Damage to Institutions Dedicated to Religion or Education

5. Wanton Crimes

5.1. Unlawful and Wanton Extensive Destruction and Appropriation of Property

5.2. Wanton Destruction of Cities, Towns or Villages, or Devastation not Justified by Military Necessity

6. General Remarks and Conclusion

\section{Introduction}

Even though more than a decade has passed since the creation of the International Criminal Tribunal for the Former Yugoslavia (ICTY/Yugoslavia Tribunal), the law of the most fundamental concept in international criminal law - mens rea - remains unsettled. ${ }^{1}$ Unlike the Statute of the International Criminal Court (ICC), that of the ICTY lacks a general provision on the mental element. ${ }^{2}$ In the absence of such a provision, the issue was left to judges sitting at the ICTY to determine the requisite mens rea for each crime under the subject matter jurisdiction of the Tribunal. Some judges viewed criminal intent to encompass a cognitive element of knowledge and a volitional element

1 The International Tribunal for the Prosecution of Persons Responsible for Serious Violations of International Humanitarian Law Committed in the Territory of Former Yugoslavia since 1991 was established pursuant to the Security Council Resolution 827 of 25 May 1993 (UN Doc. S/RES/827 (1993).

2 Professor Schabas noted that "[a] literal interpreter of the statute [.] might argue that absent words in the definitions of crimes indicating a mental element, it should be sufficient to establish that the accused perpetrated the material act or mission. Given the silence of legislation respecting the mental element of crime, common law justice systems have taken the view that the mental element is a presumption that can only be set aside by precise and specific legislation. Essentially this is the same approach that the Tribunal[.] [has] taken. It is consistent with general principles of law. Moreover, it is probably mandated by the presumption of innocence, which is enshrined in international human rights law as well as in [Article 21(3) of the ICTY Statute]" see William A. Schabas, The U.N. International Criminal Tribunals: The former Yugoslavia, Rwanda and Sierra Leone, (Cambridge: Cambridge University Press, 2006) 293. 
of acceptance, ${ }^{3}$ whereas others were of the opinion that mere foreseeability of harm is sufficient to trigger the criminal responsibility of individuals for serious violations of international humanitarian law. ${ }^{4}$ Some judges employed common law terms such as direct intent, indirect intent and recklessness, whereas others adhered to continental law terms such as dolus directus and dolus eventualis, regardless of the vast diversity between these terms. In a few cases, the Chambers applied a subjective test in order to ascertain the guilt of the accused, while in other cases, the objective test was clearly adopted.

Through its jurisprudence, the Yugoslavia Tribunal has made enormous efforts to assign various types of mens rea for different crimes under its Statute. In descending order, these degrees of mens rea are the following: special intent (dolus specialis, dol aggravé); direct intent or dolus directus; advertant recklessness or dolus eventualis. ${ }^{5}$ In many judgments, the ICTY adopted an element analysis, requiring different degrees of mens rea with regard to each of the material elements of an offence. ${ }^{6}$

The present study is an attempt to clarify several issues with regard to the law of mens rea as developed in the case law of the Yugoslavia Tribunal. Among these issues are the following: what precisely is to be understood by the terms "specific intent", "special intent", "dolus specialis", "surplus intent", or "with intent to"? Similarly, what are the precise meanings of the terms "deliberately", "intention", "intent", "intentionally", "wilful or wilfully", "knowledge", and "wanton" as provided for in the ICTY Statute or as employed by the Chambers within its judgments. For example, what is the actual meaning of the term "wilful"? Does the term require a proof of direct intent, indirect intent, dolus eventualis, or recklessness? Does the meaning of the term differ when it is attached to different offences under the Statute?

Other confusion arises regarding the mens rea for "wilful killing" and murder in establishing whether foresight of probable consequences would amount to intention in the strict sense, or whether it is mere evidence from which intent may be inferred. Is it the act which should be intentional or the consequence or both? Where a factual or circumstance element constitutes

See Prosecutor v. Naser Orić, Case No. IT-03-68-T, Trial Judgment, 30 June 2006, (Orić Trial Judgment) para. 279.

${ }^{4}$ Surprisingly, the Blaškić Trial Chamber stretched the fault element required for serious violations of Article 2 of the ICTY Statute to reach the boundaries of criminal negligence, see Prosecutor v. Tihomir Blaškić, Case No. IT-95-14-T, Trial Judgment, 3 March 2000 (Blaškić Trial Judgment) para. 152.

5 Since the mens rea requirement of different modes of participation under Article 7(1) and $7(3)$ of the ICTY Statute falls beyond the scope of this paper, "negligence" as a fault element will not be discussed in the present study.

${ }^{6}$ See note 25 infra and the accompanying text. 
an ingredient element of an offence (i.e. the civilian status of the victims Article 3 ICTY Statute) which degree of awareness has to be established on the part of the accused, if any? To put it differently, is it a question of knowledge, recklessness, or mere negligence, and is the applied test objective or subjective?

The above queries will be discussed and examined through a systematic analysis of the case law of the ICTY. ${ }^{7}$

7 The present study covers the following case law of the ICTY: Prosecutor v. Zlatko Aleksovski, Case No. IT-95-14/1-T, Trial Judgment, 25 June 1999 (Aleksovski Trial Judgment); Prosecutor v. Zlatko Aleksovski, Case No. IT-95-14/1-A, Appeal Judgment, 24 March 2000 (Aleksovski Appeal Judgment); Prosecutor v. Vidoje Blagojević and Dragan Jokić, Case No. IT-02-60-T, Trial Judgment, 17 January 2005 (Blagojević Trial Judgment); Prosecutor v. Tihomir Blaškić, Case No. IT-95-14-T, Judgment, 3 March 2000 (Blaškić Trial Judgment); Prosecutor v. Tihomir Blaškić, Case No. IT-95-14-A, Appeal Judgment, 29 July 2004 (Blaškić Appeal Judgment); Prosecutor v. Radoslav Brdanin, Case No. IT-99-36-T, Trial Judgment, 1 September 2004 (Brdanin Trial Judgment); Prosecutor v. Radoslav Brdanin, Decision on the Motion for Acquittal Pursuant to Rule 98 bis, Case No. IT-99-36-T, 28 November 2003 (Brdanin Rule 98 Trial Decision); Prosecutor v. Zejnil Delalić et al., Case No. IT-96-21-T, Trial Judgment, 16 November 1998 (Čelebići Trial Judgment); Prosecutor v. Anto Furundžija, Case No. IT-95-17/1-T, Trial Judgment, 10 December 1998 (Furundžija Trial Judgment); Prosecutor v. Stanislav Galić, Case No. IT-98-29, Trial Judgment, 5 December 2003 (Galić Trial Judgment); Prosecutor v. Enver Hadžihasanović \& Amir Kubura, Case No. IT-01-47-T, Decision on Rule 98 bis Motion for Judgment of Acquittal, 27 September 2004 (Hadžihasanović Rule 98 Trial Decision); Prosecutor v. Sefer Halilović, Case No. IT-01-48-T, 16 November 2005 (Halilović Trial Judgment); Prosecutor v. Goran Jelisić, Case No. IT-9510-T, Trial Judgment, 14 December 1999 (Jelisić Trial Judgment); Prosecutor v. Goran Jelisić, Case No. IT-95-10-A, Appeal Judgment, 5 July 2001 (Jelisić Appeal Judgment); Prosecutor v. Dario Kordić \& Mario Čerkez, Case No. IT-95-14/2-T, Trial Judgment, 26 February 2001 (Kordić Trial Judgment); Prosecutor v. Dario Kordić \& Mario Čerkez, Case No. IT-95-14/2-A, Appeal Judgment, 17 December 2004 (Kordić Appeal Judgment); Prosecutor v. Milorad Krnojelac, Case No. IT-97-25-T, Trial Judgment, 15 March 2002 (Krnojelac Trial Judgment); Prosecutor v. Milorad Krnojelac, Case No. IT-97-25-A, Appeal Judgment, 17 September 2003 (Krnojelac Appeals Judgment); Prosecutor v. Radislav Krstić, Case No. IT-98-33-T, Trial Judgment, 2 August 2001 (Krstić Trial Judgment); Prosecutor v. Dragoljub Kunarac et al., Case No. IT-96-23/1-T, Trial Judgment, 22 February 2001 (Kunarac Trial Judgment); Prosecutor v. Dragoljub Kunarac et al., Case No. IT-96-23\&23/1-A, Appeal Judgment, 12 June 2002 (Kunarac Appeal Judgment); Prosecutor v. Miroslav Kvoćka et al., Case No. IT-98-30/1-A, Appeal Judgment, 28 February 2005 (Kvoćka Appeal Judgment); Prosecutor v. Fatmir Limaj et al., Case No. IT-03-66-T, Trial Judgment, 30 November 2005 (Limaj Trial Judgment); Prosecutor v. Mladen Naletilić and Vinko Martinović, Case No. 98-34-T, Trial Judgment, 31 March 2003 (Naletilić Trial Judgment); Prosecutor v. Naser Orić, Case No. IT-03-68-T, Trial Judgment, 30 June 2006, (Orić Trial Judgment); Prosecutor v. Milomir Stakić, Case No. IT-97-24-T, Trial Judgment, 31 July 2003 (Stakić Trial Judgment); Prosecutor v. Milomir Stakić, Case No. IT-97-24-T, Decision on Rule 98 bis Motion for Judgment of Acquittal, 31 October 2002 (Stakić Rule 98 Trial Decision); Prosecutor v. Milomir Stakić, Case No. IT-97-24-A, Appeal Judgment, 22 March 2006 (Stakić Appeal Judgment); Prosecutor v. Pavle Strugar, Case No. IT-01-42-T, Trial Judgment, 31 January 


\section{Special Intent or Primary Purpose Crimes}

\subsection{Terror Against the Civilian Population}

The crime of terror against the civilian population was first defined by Trial Chamber I of the ICTY in the Galić case. ${ }^{8}$ The Chamber found that a "protracted campaign of shelling and sniping upon civilian areas of Sarajevo and upon the civilian population" constitutes a serious violation of the laws or customs of war. ${ }^{9}$ While the acts of terrorising the civilian population is not explicitly found in the ICTY Statute, these acts qualified, inter alia, as a crime of terror as set forth in Article 51(2) of the first Additional Protocol to the Geneva Conventions of 1949 and are, accordingly, punishable under Article 3 of the ICTY Statute. ${ }^{10}$ Based on the prohibition enshrined in Article 51(2) of the first Additional Protocol, the Chamber defines the objective and subjective elements of the offence of "terror against civilian population" as follows:

“(i) acts of violence [conduct element] directed against the civilian population or individual civilians not taking direct part in hostilities [circumstance element] causing death or serious injury to body or health within the civilian population [result element];

(ii) the offender wilfully made the civilian population or individual civilians not taking direct part in hostilities the object of those acts of violence [mens rea];

2005 (Strugar Trial Judgment); Prosecutor v. Pavle Strugar, Case No IT-01-42-T, Decision on Rule 98 bis Motion for Judgment of Acquittal, 21 June 2004 (Strugar Rule 98 Trial Decision); Prosecutor v. Duško Tadić, Case No. IT-94-1-T, Trial Judgment, 7 May 1997 (Tadić Trial Judgment); Prosecutor v. Duško Tadić, Case No. IT-94-1-AR72, Decision on the Defence Motion for Interlocutory Appeal on Jurisdiction, 2 October 1995 (Tadić Interlocutory Appeal Decision); Prosecutor v. Mitar Vasiljević, Case No. IT-98-32-T, Trial Judgment, 29 November 2002 (Vasiljević Trial Judgment); Prosecutor v. Mitar Vasiljević, Case No. IT-98-32-A, Appeal Judgment, 25 February 2004 (Vasiljević Appeal Judgment).

8 Galić Trial Judgment, paras. 65-66. Whereas in the Galić case "terrorisation" was pleaded as an independent count, namely as a violation of the laws or customs of war pursuant to Article 3 of the ICTY Statute, in the Blagojević case, the Prosecution has charged "the terrorising of Bosnian Muslim civilians in Srebrenica and at Potoćari as an act of persecution" see Blagojević Trial Judgment, para. 8.

${ }^{9}$ Galić Trial Judgment, paras. 132-133.

${ }^{10}$ Article 51(2) of Additional Protocol I to the Geneva Conventions of 12 August 1949, and Relating to the Protection of Victims of International Armed Conflicts (Protocol I), Geneva, 8 June 1977 provides: "The civilian population as such, as well as individual civilians, shall not be the object of attack. Acts of threats of violence the primary purpose of which is to spread terror among the civilian population are prohibited." 
(iii) the above offence was committed with the primary purpose of spreading terror among the civilian population [mens rea]."11

The Chamber further found that the actual infliction of terror is not a constitutive legal element of the crime of terror. ${ }^{12}$ Accordingly, the Prosecution needs only to prove that the acts of terror were carried out in an atmosphere of terror among a civilian population. With respect to the men rea requisite of this offence, the Galic Trial Chamber found that the phrase "primary purpose", which signifies the mens rea of the crime of terror, is to be understood as excluding dolus eventualis or recklessness from the intentional state specific to terror. ${ }^{13}$ Thus, in order to sustain a conviction for this offence:

"[T]he Prosecution is required to prove not only that the Accused accepted the likelihood that terror would result from the illegal acts - or, in other words, that he was aware of the possibility that terror would result - but that was the result which he specifically intended. The crime of terror is a specific-intent crime." 14

The above quoted judgment clearly shows that the mens rea required for this offence is established where it is proved that the perpetrator's primary purpose or his conscious objective was directed to spread terror among civilian population. However, there are two important aspects with regard to the mens rea of this offence. First, the crime of terror against the civilian population requires not merely the establishment of a 'specific intent' as set out in element (iii) but also entails different mental states with respect to different material elements of the offence. That is to say, elements (i) \& (ii) have their own "offensive package" actus reus and mens rea. This "offensive package" consists of the following material elements: "acts of violence" (conduct element); "directed against the civilian population" (circumstance element); "causing death or serious injury to body or health" (result element). These material elements have their own mental state - the element of wilfulness. ${ }^{15}$ Thus, the presence or the absence of such "surplus of intent" has nothing to do with the survival of the "offensive package", but, where this "surplus of

${ }^{11}$ Galić Trial Judgment, para. 133, (emphasis added). The original text of element (iii) reads as follows "the above offence was committed ...", however, it is preferable to substitute the word "acts" for "offence".

${ }^{12}$ Galić Trial Judgment, para. 134.

${ }^{13}$ Ibid., para. 136.

${ }^{14}$ Ibid., (emphasis added).

${ }^{15}$ According to the Galić Judgment, "willfully" as a mens rea standard is satisfied whenever the accused acts deliberately or recklessly, Galić Trial Judgment, para. 596. 
intent" exists, it does aggravate the nature of this package to reach the threshold of the crime of terror. ${ }^{16}$

The second aspect is the degree of mens rea required with regard to the circumstance element of this offence - the civilian status of the person attacked. Interestingly, the Galic Trial Chamber addressed this point while examining the facts of "Incident 16" of the present case, namely, "Scheduled Sniping" ${ }^{17}$ The Chamber found that "the manner in which the victim was dressed . . . and the activity in which she was engaged at the time of the incident clearly reflected her civilian status". ${ }^{18}$ Taking all circumstances into consideration, the Chamber found that "the perpetrator, or a reasonable person in those circumstances, should not have ignored the probability that the victim was a civilian." 19 It concluded, "the victim was targeted from the SRKcontrolled area, if not with the intention to attack her as a civilian, then at least in full awareness of the high risk that the target was a civilian." ${ }^{20}$

It is not clear from the judgment whether the fault element required for the circumstance element is intention, recklessness, or mere negligence (a reasonable person ... should not have ignored). However, one can discern that mere negligence is not a sufficient fault element with regard to the circumstance element since wilfulness as set out in element (ii) has to cover the material elements of this offensive package.

Furthermore, the words employed by the Galić Trial Chamber, in defining the degree of mens rea required with regard to the circumstance element, deserve more attention. First, it seems preferable not to use the word intention with regard to the circumstance element, as circumstances are always related to the knowledge or awareness and not to the actor's intention. ${ }^{21}$ The second point is an outcome of the first, when knowledge of the existence of a particular fact is an element of the offence, two different levels of awareness can be established: (i) the perpetrator is aware of the existence of such circumstances (actual knowledge); or (ii) the perpetrator is aware of the high probability of its existence. ${ }^{22}$ There is, however, another degree of awareness

${ }^{16}$ The term "surplus of intent" was first employed by the Yugoslavia Tribunal in reference to the "specific intent" of the crime of genocide, in Stakic Rule 98 Trial Decision, paras. 17, 26, 29.

${ }^{17}$ The Prosecution alleges two specific incidents of targeting of civilians as representative small arm fire against civilians in an area called Briješko brdo.

18 Galić Trial Judgment, para. 433, (emphasis added).

19 Ibid., (emphasis added).

20 Ibid.

21 See Galić Trial Judgment, para. 433.

22 See the Model Penal Code (MPC) § 2.02 (2)(b)(i), § 2.02(7). For a commentary on the MPC see The American Law Institute, Model Penal Code and Commentaries, (Philadelphia: The American Law Institute, 1985). 
with regard to the circumstance element. A person is said to be reckless as to a circumstance element "if he is aware of the possibility that such a circumstance exists and does an act regardless of it." 23 In cases where a lower threshold is sufficient, the test has to be objective: "a reasonable person in those circumstances should not have ignored the probability of its existence." 24

However, the beauty of this judgment is that it implicitly establishes the concept of "element analysis" in place of "offence analysis." The former concept requires the Prosecution to prove beyond reasonable doubt that the defendant carried out each of the material elements of the offence (conduct, circumstances, and result) with a culpable state of mind. ${ }^{25}$

\subsection{Torture}

Torture is outlawed in the legislation of nearly all States and is prohibited under both conventional and customary international law, whether in times of peace or armed conflict. ${ }^{26}$ In Limaj et al, Trial Chamber II concurred with previous jurisprudences of the ICTY that the "definition of torture is the same regardless of the Article of the Statute under which the accused has been charged." ${ }^{27}$ Both Trial Chambers and Appeals Chambers of the ICTY agreed that, in order to sustain a conviction for the offence of torture, the following elements must be met:

"(i) there must be an act or omission [conduct element] inflicting severe pain or suffering, whether physical or mental [result element];

${ }^{23}$ See Glanville Williams, Criminal Law: The General Part, (London: Steven \& Sons, 2d ed. 1961) 56.

${ }^{24}$ See Galić Trial Judgment, para. 433.

${ }^{25}$ Ibid., § 2.02(4) of the Model Penal Code states: ("Prescribed Culpability Requirement Applies to All Material Elements.") "When the law defining an offence prescribes the kind of culpability that is sufficient for the commission of an offence, without distinguishing among the material elements thereof, such provision shall apply to all the material elements of the offence, unless a contrary purpose plainly appears."

${ }^{26}$ The corpus of international humanitarian law applicable during an armed conflict which embodies this norm includes the Hague Conventions, especially, Articles 4 and 46 of the Regulations annexed to Convention IV of 1907 Respecting the Laws and Customs of War on Land, read in conjunction with the so-called "Martens Clause" laid down in the Preamble to the same Convention; common Article 3 and grave breaches of the 1949 Geneva Conventions; Article 2 of Additional Protocol I; and Articles 5(2)(e), 6, 7 of Additional Protocol II. The provisions of the Hague Conventions regarding prisoners of war or those relating to civilians expressly prohibit torture. However, it is to be observed that torture is, in any event implicitly forbidden against these individuals, since the provisions prescribe that they be treated with humanity. See D.H. Derby, 'Torture', in M. Cherif Bassiouni (ed), 1 International Criminal Law (New York: Transnational Publishers, 2nd ed. 1999) 719. See also Schabas, The U.N. International Criminal Tribunals, supra note 2, 205-209. 
(ii) the act or omission must be intentional [mens rea as to the conduct and result elements]; and

(iii) the act or omission must have been carried out with a specific purpose [mens rea-primary purpose] such as to obtain information or confession, to punish, intimidate or coerce the victim or a third person, or to discriminate, on any ground, against the victim or a third person." 28

With regard to the mens rea required for the crime of torture, the jurisprudence of the ICTY holds consistent that two mental states are required in order to sustain a conviction for this offence. The first mental state required is a direct intent: "the perpetrator must have intended to act in a way which, in the normal course of events, would cause severe pain or suffering, whether physical or mental to his victim." 29 The test is subjective, it has to be established that the actor (and not a reasonable person), in carrying out the proscribed conduct, was aware that it would almost certainly cause severe pain or suffering to his victim..$^{30}$ In light of the above, any lower degree of mens rea (i.e. dolus eventualis or recklessness) is not sufficient for this "offensive package". ${ }^{31}$

Yet, in order for this "offensive package" to fall under the definition of torture, it must be established that it has been carried out with a specific purpose, such as to obtain information or confession, to punish, intimidate or coerce the victim or a third person, or to discriminate, on any ground, against

${ }^{27}$ Limaj Trial Judgment, para. 235, fn. 723; Brdanin Trial Judgment, para. 482; Krnojelac Trial Judgment, para. 178; Furundžija Trial Judgment, para. 139. It is to be noted that torture is sanctioned as a grave breach, violation of the laws and customs of war, and as a crime against humanity, under Articles 2(b), 3, and 5 of the ICTY Statute respectively.

${ }^{28}$ Limaj Trial Judgment, para. 235; Kunarac Appeals Judgment, paras. 142, 144, confirming Kunarac Trial Judgment, para. 497; Brdanin Trial Judgment, para. 481; Krnojelac Trial Judgment, para. 179. It is to be noted that where "torture" is charged as a crime against humanity under Article 5 of the ICTY Statute, knowledge of the nature of the attack is considered additional element which must be established on the part of the accused.

${ }^{29}$ Limaj Trial Judgment, para. 238; Kunarac Appeal Judgment, para. 153. The Limaj Trial Chamber used the term "direct intent"; Kunarac Appeal Chamber, and Krnojelac Trial Chamber used the term "deliberately", paras. 154, 184 respectively; Furundžija and Kunarac Trial Chambers used the term "intentional" para. 162, para. 497 respectively. Thus, "direct intent", "intentional", and "deliberately" are mens rea terms used interchangeably by the ICTY.

${ }^{30}$ See Andrew Byrnes, 'Torture and Other Offences Involving the Violation of the Physical or Mental Integrity of the Human Person' in Gabrielle Kirk Mc Donald and Olivia SwaakGoldman (eds.), 1 Substantive and Procedural Aspects of International Criminal Law, (The Hague: Kluwer Law International, 2000) 212.

31 Guénaël Mettraux, International Crimes and the ad hoc Tribunals, (Oxford: Oxford University Press, 2005) 116. 
the victim or a third person. ${ }^{32}$ As the Krnojelać Judgement held, "[t]orture as a criminal offence is not a gratuitous act of violence; it aims, through the infliction of severe mental or physical pain, to attain certain result or purpose." ${ }^{33}$ Thus, "in the absence of such purpose or goal, even very severe infliction of pain would not qualify as torture pursuant to Article 3 or Article 5 of the Tribunal's Statute." 34

The prohibited purpose must be neither the sole nor the main purpose of inflicting severe pain or suffering. ${ }^{35}$ In other words, the acts need not have been perpetrated solely for one of the purposes prohibited by international law. ${ }^{36}$ If one prohibited purpose is fulfilled by the conduct, the fact that such conduct was also intended to achieve another non-listed purpose is immaterial. In Kunarac, the Appeals Chamber concurred with the Trial Chamber that "the Appellants deliberately committed the acts of which they were accused and did so with the intent of discriminating against their victims because they were Muslim." ${ }^{37}$ In addition to this discriminatory purpose, the Appeals Chamber noted that "the acts were committed against one of the victims with the purpose of obtaining information." ${ }^{38}$

It is not clear in the jurisprudence of the ICTY if the actual achievement of one or more of the accused's purpose (i.e. obtaining information or confession) is a legal ingredient element in this offence. However, it is suggested that, similar to the crime of terror and genocide, the actual achievement of the accused's purpose is not a constitutive element of the crime of torture.

To sum up, the crime of torture in the subject matter jurisdiction of the ICTY requires an additional mental element, namely, specific purpose or special intent, which goes beyond the intent to inflict severe pain. ${ }^{39}$

\subsection{Persecution as a Crime Against Humanity}

According to the ICTY Appeals Chambers, the crime of persecution, sanctioned under Article 5(h) of the Statute, consists of an act or omission that:

32 Limaj Trial Judgment, para. 239.

${ }^{33}$ Krnojelac Trial Judgement, para. 180.

${ }^{34}$ Ibid.

35 Čelebići Trial Judgment, para. 470.

36 Kunarac Appeal Judgement, para. 155.

37 Ibid., para. 154.

38 Ibid.

39 Most notably, the requirement of a specific purpose for the crime of torture was deliberately omitted from the Rome Statute as well as from Article 7(1)(f) of the Elements of Crimes. A footnote to the Elements reads: "It is understood that no purpose need be proved for this crime." See the Finalized draft text of the Elements of Crimes, U.N. Preparatory Commission for the International Criminal Court, U.N. Doc. PCNICC/2000/1/Add.2 (2000), Article 7(1)(f), fn. 14. 
“(i) discriminates in fact and which denies or infringes upon a fundamental right laid down in international customary or treaty law (actus reus); and

(ii) is carried out deliberately with the intention to discriminate on one of the listed grounds, specifically race, religion or politics (mens rea). ${ }^{.40}$

As for the actus reus of persecution, the act or omission must have discriminatory consequences. ${ }^{41}$ That is to say, "the persecutory acts must be intended to cause, and result in, an infringement on an individual's enjoyment of a basic or fundamental right." ${ }^{\prime 2}$ Accordingly, if the perpetrator was mistaken and the victim of discrimination did not actually qualify under these racial, religious or political grounds, no crime of persecution could be found. In German criminal law, this is known as error in persona. This error in persona could negate the mental element in cases of lacking legal equivalence between the injured object of the act as imagined by the perpetrator, and the one actually injured. ${ }^{43}$

The mens rea of persecution consists of different degrees of mental states which must be established exclusively, before a reasonable Trial of fact can return a verdict of this offence. The Kordić Trial Chamber set forth a two-part test in order to hold a person criminally liable for the crime of persecution:

"The accused must have had the ... [particular] intent to commit the underlying act (such as murder, extermination, or torture). Then, if the act is to entail additional, criminal liability as a crime against humanity, the accused must also have had the requisite mens rea for crimes against

40 Stakić Appeal Judgment, para. 327; Kordić Appeal Judgment, para. 101; Blaškić Appeal Judgment, para. 131; Vasiljević Appeal Judgment, para. 113; Krnojelac Appeal Judgment, para. 185; Blagojević Trial Judgment, para. 579. For more details on the objective and subjective elements of persecution in the case law of the ICTY, see Mohamed Elewa Badar, 'From the Nuremberg Charter to the Rome Statute: Defining the Elements of Crimes against Humanity', 5 San Diego International Law Journal (2004) 73, 122-140.

${ }^{41}$ Krnojelac Appeal Judgment, paras. 185, 200-02, citing with approval Krnojelac Trial Judgment, para. 431; Blagojević Trial Judgment, para. 583; Stakić Trial Judgment, para. 733; Vasiljević Trial Judgment, para. 245.

42 Stakić Trial Judgment, para. 733 (emphasis in original), citing with approval Tadić Trail Judgment, para. 715. The Stakić Trial Chamber found that the accused guilty of persecutions based on the underlying acts of murder and deportations, as well as torture, physical violence, rape, constant humiliation and degradation, and destruction of or wilful damage to religious and cultural buildings.

${ }^{43}$ For more information on error in persona in German criminal law see Mohamed Elewa Badar, 'Mens Rea - Mistake of Law and Mistake of Fact in German Criminal Law: A Survey for International Criminal Tribunals', 5 International Criminal Law Review (2005) 203, 238-9. 
humanity, which has been defined as knowledge of the context of a widespread or systematic attack directed against a civilian population. With regard to the crime of persecution, a particular intent is required, in addition to the specific intent (to commit the act and produce its consequences) and the general intent (the objective knowledge of the context in which the accused acted). This intent - the discriminatory intent - is what sets the crime of persecution apart from other Article 5 crimes against humanity." 4

The Krnojelać Trial Judgment further provides some clarity as regards the quality or degree of discriminatory intent required. The judgment states that the accused "must consciously intend to discriminate" and that it "is not sufficient for the accused to be aware that he is in fact acting in a way that is discriminatory." 45 The terms "discriminatory intent", as viewed by the Stakic Trial and Appeals Chambers, "amounts to the requirement of a "dolus specialis" ${ }^{46}$ Accordingly, recklessness, dolus eventualis or gross negligence are not a sufficient mens rea for the crime of persecution. ${ }^{47}$ One commentator observed that this additional element of discriminatory intent amounts to an "aggravated criminal intent". ${ }^{4}$

To the extent that the accused acted as a direct or principal perpetrator in carrying out the crime of persecution, the Vasiljević and Kornejelać Judgments are certainly laudable. ${ }^{49}$ In such cases where the accused is

44 Kordić Trial Judgment, paras. 211-12, (emphasis added). It is not clear if the Trial Chamber wanted to say that the underlying act requires a "specific intent" to the effect that purpose is required.

45 Krnojelac Trial Judgment, para. 435; Vasiljević Trial Judgment, para. 248; Kordić Trial Judgment, para. 217.

46 Stakić Appeal Judgment, para. 329, endorsing Stakić Trial Judgment, para. 737.

${ }^{47}$ Being aware of the complexity of proving such a higher threshold of mens rea, the Prosecution argued that it suffices to show that the accused had objective knowledge that his acts fitted within widespread or systematic attack based on discriminatory intent. see Kordic Trial Judgment, para. 216. This argument was rejected by the Kordić Trial Chamber in paragraph 249 of its Judgment on the following grounds:

"An adoption of the Prosecution's formulation of the requisite mens rea would eviscerate the distinction between persecution and the other enumerated crimes against humanity. Such an approach also would dilute the gravity of persecution as a crime against humanity, making it difficult to reach principled decisions in sentencing. Given the fact that the actus reus of persecution overlaps with the actus reus of other Article 5 crimes, the sole distinction between the two lies in the mens rea."

48 Kai Ambos, 'Selected Issues Regarding the 'Core Crimes' in International Criminal Law', 19 Nouvelles Études Pénales (2004) 219, 259 (emphasis in original).

${ }^{49}$ In these two cases, the accused were closely related to the actual commission of crimes. In such cases, proof is required of the fact that the direct perpetrator acted with discriminatory intent in relation to the specific act, see Stakić Trial Judgment, para. 741. 
closely related to the actual commission of crimes, one might agree that proof is required of the fact that the direct perpetrator acted with discriminatory intent in relation to the specific act. However, this requirement might be problematic in cases where the accused is considered the co-perpetrator behind the commission of the crime of persecution together with other persons. Addressing this point, the Stakić Trial Chamber ruled that:

"In cases of indirect perpetratorship, proof is required only of the general discriminatory intent of the indirect perpetrator in relation to the attack committed by the direct perpetrators/actors. Even if the direct perpetrator/actor did not act with a discriminatory intent, this, as such, does not exclude the fact that the same act may be considered part of a discriminatory attack if only the indirect perpetrator had the discriminatory intent." ${ }^{50}$

In the paragraph prior to the above quoted judgment, the Trial Chamber held that "proof of a discriminatory attack against a civilian population is a sufficient basis to infer the discriminatory intent of an accused for the acts carried out as part of the attack in which he participated as a (co-)perpetrator." ${ }^{1}$

According to the Stakic Judgment, once it is demonstrated that the coperpetrator was aware of the nature of the attack, he is considered to posses the discriminatory intent (without further evidence). One might disagree with the Stakic finding on the basis that awareness of the circumstances (the discriminatory nature of the attack) does not necessarily imply the existence of intention, although it may be a fact from which, when considered with all the other evidence, can lead a reasonable Trial of fact to infer the discriminatory intent on the part of the co-perpetrator. ${ }^{52}$ Furthermore, such "automatic attribution" of discriminatory intent might violate the rights of the accused. ${ }^{53}$ In Kvočka, the Appeals Chamber agrees with the Appellant that "the discriminatory intent of crimes cannot be inferred directly from the general discriminatory nature of an attack characterized as a crime against humanity." 54 The Appeals Chamber went on to hold that "the discriminatory intent, however, may be inferred from the context of the attack, provided it is substantiated by the surrounding circumstances of the crime." 55

${ }^{50}$ Stakić Trial Judgment, para. 743.

51 Ibid., para. 742.

52 In Kordić, the Trial Chamber inferred the discriminatory intent of the accused from their active participation of the common criminal design. The Trial Chamber concludes that discriminatory intent of a perpetrator can be inferred from knowingly participating in a system or enterprise that discriminates on political, racial or religious grounds. Kordić Trial Judgment, paras. 829, 831.

${ }^{53}$ Radić Appeal Brief, para. 71, quoted in Kvoćka Appeal Judgment, para. 364.

${ }^{54}$ Kvoćka Appeal Judgment, para. 366.

55 Ibid. 


\subsection{Genocide}

Generally speaking, Article 4, paragraphs (2) and (3) of the ICTY Statute is a verbatim reproduction of Articles II and III respectively of the 1948 Convention on the Prevention and Punishment of the Crime of Genocide. ${ }^{56}$ The provision set out in Article 4 of the Statute characterizes genocide by the following constitutive elements:

"(i) the underlying act of the offence, which consists of one or several of the actus reus enumerated in subparagraphs (a) to (e) of Article 4(2) carried out with the mens rea required for the commission of each;

(ii) the specific intent of the offence, which is described as the intent to destroy, in whole or in part, a national, ethnical, racial or religious group, as such." ${ }^{57}$

Similar to other "specific intent" or "specific purpose" crimes under the subject matter jurisdiction of the ICTY, the level of intent required for the crime of genocide is the dolus specialis. ${ }^{58}$ The absence of this dolus specialis, on

56 Convention on the Prevention and Punishment of the Crime of Genocide, (1951) 78 UNITS 277. Article 4 of the ICTY Statute states:

[...]

2. Genocide means any of the following acts committed with intent to destroy, in whole or in part, a national, ethnical, racial or religious group, as such:

(a) killing members of the group;

(b) causing serious bodily or mental harm to members of the group;

(c) deliberately inflicting on the group conditions of life calculated to bring about its physical destruction in whole or in part;

(d) imposing measures intended to prevents birth within the group;

(e) forcibly transferring children of the group to another group.

For more details on the mental element of the crime of genocide in the jurisprudence of the International Criminal Tribunals for the former Yugoslavia and Rwanda see William A, Schabas, Genocide in International Law: The Crime of Crimes (Cambridge: Cambridge University Press, 2000) 207-256. See also Schabas, The U.N. International Criminal Tribunals, supra note 2, at 164-172.

57 Brdanin Trial Judgment, para. 681.

58 The exact scope of this sub-element was the subject of the Prosecution's third ground of appeal in the Jelišić case. The Prosecution position on the requisite degree of intent was spelled in paragraph 4.9 of the Jelisić Appeal Brief:

The Prosecutor formulated the correct mental state standard under Article 4 in paragraph 3.1 of its pre-trial brief in the present case:

The Accused committed the acts with the requisite intent if:

a. he consciously desired the acts to result in the destruction, in whole or in part, of the group, as such;

b. he knew his acts were destroying, in whole or in part, the group, as such;

c. he knew that the likely consequence of his acts would be to destroy, in whole or in part, the group, as such. 
the one hand, has nothing to do with the criminal characteristic of the enumerated acts of the crime of genocide, as those criminal acts have their own "offensive package" - material elements and mental elements. On the other hand, where the dolus specialis exits, this will aggravate the "offensive package" to fall into the realm of the crime of crimes.

In Jelisić, the Appeals Chamber defines the specific genocidal intent as "intent to destroy in whole or in part, a national, ethnical, racial or religious group, as such". ${ }^{59}$ The Appeals Chamber formulates this as a requirement that the perpetrator "seeks to achieve the destruction, in whole or in part, of a national, ethnical, racial or religious group, as such." ${ }^{00}$ The Krstić Trial Judgement states that the genocidal conduct must have been "committed with the goal of destroying all or part of a group". ${ }^{61}$ In Stakic and Barđnin, Trial Chamber II noted that the proscribed acts set out in Article 4(2) of the ICTY Statute are elevated to genocide when it is proved that the perpetrator not only wanted to commit those acts but also intended to destroy in whole or in part the targeted group, as a separate and distinct entity. ${ }^{62}$ According to Stakić, genocide is characterised and distinguished by a "surplus of intent". ${ }^{63}$

The above judgments clearly show that any lower degree of mens rea that fall short of the threshold of dolus specialis would not suffice to trigger criminal liability for the crime of genocide. To put it differently, in order to ascertain a conviction for genocide, it has to be established that, in addition to the mens rea requisite for the proscribed act(s) listed under Article 4(2) of the Statute, the Prosecution has to demonstrate that the accused' conscious object, primary purpose, or goal was to destroy in whole or in part, the group, as such.

See Prosecutor v. Goran Jelisić, Prosecutor's Appeal Brief (Redacted Version), Case No. IT-95-10-A, Submitted 14 July 2000, para. 4.9, p. 54. See also Prosecutor v. Goran Jelisić, Prosecutor's Pre-Trial Brief Case No. IT-95-10-T, 19 November 1998, para. 3.1.

59 Jelisić Appeal Judgement, para. 45. The Appeals Chamber further ruled that 'the existence of a plan or policy is not a legal ingredient of the crime', ibid., para. 48.

${ }^{60}$ Ibid., para. 46; Krstić Trial Judgement, para. 550.

${ }^{61}$ Krstić Trial Judgement, para. 571. Interestingly, in paragraph 571, the Krstić Trial Chamber opines that "some legal commentators further contend that genocide embraces those acts whose foreseeable or probable consequences is the total or partial destruction of the group without any necessity of showing that destruction was the goal of the act. Whether this interpretation can be viewed as reflecting the status of customary international law at the time the acts involved here is not clear." Among those commentators referred to by the Trial Chamber is Alexander K. A. Greenwalt, 'Rethinking Genocidal Intent: The Case for a Knowledge-Based Interpretation” 99 Columbia Law Review (1999) 2259. In his work, Greenwalt observes that the Genocide Convention's intent standard is subject to multiple interpretations, and the drafting history of this Convention does not "clearly support a purpose standard", but rather "reveals a vigorous and confused debate over the intent standard that remained alarmingly unresolved at the time of the Convention's adoption."

62 Stakić Trial Judgment, para. 520; Brđanin Trial Judgment, para. 695.

63 Stakić Trial Judgment, para. 520. 
Failure to demonstrate this surplus of intent on the part of the accused he will likely be convicted for some lesser offence under the ICTY Statute, or the offence in question may constitute an ordinary crime under national jurisdiction.

\section{Direct and Indirect Intent Crimes}

\subsection{Rape - Direct Intent Crime}

In the jurisprudence of the Yugoslavia Tribunal, the crime of rape has been charged under different headings, i.e. as a war crime under Article 3, as a crime against humanity under Article 5(g), and as persecution under Article 5(h). The constituent elements of the crime are essentially identical, provided that respective jurisdictional requirements under each article are met. ${ }^{64}$ The Kunarac Trial Chamber's articulation of the elements of rape was as follows:

"The actus reus of the crime of rape in international law is constituted by the sexual penetration, however slight:

(a) of the vagina or anus of the victim by the penis of the perpetrator or any other object used by the perpetrator; or

(b) of the mouth of the victim by the penis of the perpetrator; where such sexual penetration occurs without the consent of the victim. Consent for this purpose must be consent given voluntarily, as a result of the victim's free will, assessed in the context of the surrounding circumstances.

The mens rea is the intention to effect this sexual penetration, and the knowledge that it occurs without the consent of the victim." 65

In light of the above quoted judgment, absence of consent clearly constitutes a circumstance element of the offence of rape which has to be covered by the mental state of the accused - that the accused is aware that such a circumstance exists. Such state of mind may be inferred from all the circumstances surrounding the events, including the coercive environment in which the act took place. Accordingly, the Kunarac Trial Chamber rejected the Defence' assertion that the accused (Kunarac) was not aware of the fact that the victim did not voluntarily have sexual intercourse with him. Considering the general context of the existing wartime situation, and the specifically delicate situation

${ }^{64}$ A Trial Chamber may enter convictions for rape under both Article 3 and rape as a crime against humanity under Article 5(g) of the ICTY Statute. According to the Jelisić Appeals Judgement, Article 3 and Article 5 are crimes each containing "a special ingredient not possessed by the other." Jelisić Appeal Judgement, para. 82. But where rape is charged as part of Article 5(h) (persecution) and 5(g) and where all requirements for both charges are met, the former prevails over Article 5(g) for reasons of specificity.

${ }^{65}$ Kunarac Trial Judgment, paras. 460, 437, approved in Kunarac Appeal Judgment, para. 128. 
of the detained Muslim girls, the Trial Chamber was satisfied beyond reasonable doubt that Kunarac acted "in the full knowledge that the victim did not freely consent." ${ }^{\prime \prime 6}$

In light of the foregoing, direct intent with regard to the proscribed conduct and knowledge with regard to the circumstance element are the requisite mental states for the crime of rape.

\subsection{Outrages Upon Personal Dignity - Direct Intent Crime}

The crime of "outrages upon personal dignity" has been charged pursuant to Article 3 of the ICTY on the basis of common Article 3(1)(c) of the 1949 Geneva Conventions. ${ }^{67}$ The first ruling on the offence of "outrages upon personal dignity" as a violation of the Laws or Customs of War was rendered by the Aleksovski Trial Chamber. In this case, the Chamber examined the legal basis of outrages upon personal dignity and held that the offence was a species of inhuman treatment. ${ }^{68}$ Its elements are said to consist of the following:

"(i) that the accused intentionally committed or participated in an act or omission which would be generally considered to cause serious humiliation, degradation, or otherwise be a serious attack on human dignity; and

(ii) that he knew that the act or omission could have that effect." 69

The reason that the Trial Chamber inserted element (ii) in the above quoted judgment was to emphasize that the crime of "outrages upon personal dignity" does not require that the accused knew of the actual consequences of the act, mere knowledge of the "possible" consequences of the charged acts or omission is sufficient. ${ }^{70}$ Yet, the mens rea degree "intentionally", as set out in element (i), applies only to the nature of the conduct and not to the result

${ }^{66}$ Kunarac Trial Judgement, para. 647 (emphasis added).

${ }^{67}$ This provision expressly prohibits "outrages upon personal dignity, in particular humiliation and degrading treatment." It is well established under the jurisprudence of the Yugoslavia Tribunal that Article 3 of the Statute permits the prosecution of offences falling under common Article 3 of the Geneva Conventions of 1949, Kunarac Trial Judgment, para. 498; See also Tadić Interlocutory Appeal Decision, para 89.

${ }^{68}$ Aleksovski Trial Judgment para. 54. The Aleksovski Appeals Chamber concurred that outrages upon personal dignity is a category of inhuman treatment proscribed by Common Article 3 that resides within the broader concept of human dignity, Aleksovski Appeals Judgment, para. 26.

${ }^{69}$ Kunarac Trial Judgment, paras. 507, 514; Kunarac Appeal Judgment, paras. 161, 163.

${ }^{70}$ Kunarac Trial Judgment, para. 512. On appeal, the Appeals Chamber rejected the appellant's argument that, to be convicted under that heading, the perpetrator needed to know that his acts or omission would have had such an effect, Kunarac Appeal Judgment, paras. 164-166. 
element. The relevant statement of the Kunarac Trial Judgment deserves lengthy quotation:

"The Trial Chamber is of the view that the requirement of an intent to commit the specific act or omission which gives rise to criminal liability in this context involves a requirement that the perpetrator be aware of the objective character of the relevant act or omission. It is a necessary aspect of a true intention to undertake a particular action that there is an awareness of the nature of that act. ${ }^{71}$ As the relevant act or omission for an outrage upon personal dignity is an act or omission which would be generally considered to cause serious humiliation, degradation or otherwise be a serious attack on human dignity, an accused must know that his act or omission is of that character. ... This is not the same as requiring that the accused knew of the actual consequences of the act."'72

Thus, the offence of outrages upon personal dignity requires two different degrees of mens rea with regard to the nature of the conduct and the proscribed result. The former requires intent - the perpetrator intend to humiliate the victim, whereas the latter requires mere awareness of a substantial risk - yet not certainty of the occurrence of the proscribed results. ${ }^{73}$

The required knowledge could be easily inferred from the factual findings. When 'the objective threshold of the offence' - that is the serious consequence as described in element 1 - is met, "it would be rare that the perpetrator would not also know that the acts could have that effect". ${ }^{74}$

The Kunarac Appeals Judgement held that the nature of the acts inflicted, rapes, forced nudity, degrading submissions, "reached the objectivity threshold", and, therefore, it would appear "highly improbable that the appellant was not aware that his acts could have such an effect." 75 The Appeals Chamber concurs with the Trial Chamber in that the crime of outrages upon personal dignity requires only knowledge of the possible consequences of the charged act or omission. ${ }^{76}$

${ }^{71}$ Kunarac Trial Judgment, para. 512.

${ }^{72}$ Kunarac Trial Judgment, para. 512 (emphasis in original).

73 According to the Kunarac Trial Chamber, the crime of outrages upon personal dignity requires that the accused knew that his act or omission could cause serious humiliation, degradation or otherwise be a serious attack on human dignity, Kunarac Trial Judgment, para. 514.

${ }^{74}$ Kunarac Trial Judgement, para. 512.

${ }^{75}$ Kunarac Appeal Judgement, para. 166.

${ }^{76}$ Kunarac Appeal Judgment, para. 165. 


\subsection{Extermination - dolus directus or dolus eventualis}

The jurisprudence of the Yugoslavia Tribunal has consistently held that, apart from the question of scale, the core elements of extermination are essentially similar to those required for "wilful killing" under Article 2 and "murder" under Articles 3 and 5 of the Statute..$^{77}$ The Blagojević, Brđanin and Stakić Trial Chambers agree that in addition to the general requirements which must be established for a finding of a crime against humanity as provided for in the chapeau element of Article 5 of the Statute, the elements of extermination are the following:

"(i) act or omission that results in the death of persons on a massive scale (actus reus), and

(ii) the intent to kill persons on a massive scale, or to inflict serious bodily injury or create conditions of life that lead to the death in the reasonable knowledge that such act or omission is likely to cause the death of a large number of persons (mens rea)." 78

The act amounting to extermination "must be collective in nature rather than directed towards singled out individuals." 79 This requirement of massiveness as a constitutive element of the actus reus of extermination has to be determined on a case-by-case analysis of all relevant factors. ${ }^{80}$

As for the mens rea for the crime of extermination, the jurisprudence of the Yugoslavia Tribunal mirrors the inconsistency with regard to this issue. Apart from the Rwanda Tribunal's approach which expands the fault element of this offence to include gross negligence, three different approaches can be

77 Blagojević Trial Judgment, para. 571; Brdanin Trial Judgment, para. 388; Krstić Trial Judgment, para. 492; Vasiljević Trial Judgment, para. 226; Stakić Trial Judgment para. 638. The commentary on the International Law Commission Draft Code of Crimes against the Peace and Security of Mankind defines extermination in the following terms: "[e]xtermination is a crime which by its very nature is directed against a group of individuals. In addition, the act used to carry out the offence of extermination involves an element of mass destruction which is not required for murder. In this regard, extermination is closely related to the crime of genocide." See the International Law Commission Draft Code of Crimes against the Peace and Security of Mankind, Report of the International Law Commission on the work of its 48th session, 6 May-26 July 1996, Official Documents of the United Nations General Assembly's 51st session, Supplement no. 10 (A/51/10), Article 18, p. 118.

${ }^{78}$ Blagojević Trial Judgment, para. 572; Brđanin Trial Judgment, para. 388; Stakić Trial Judgment, paras. 638, 641.

79 Stakić Trial Judgment, para. 639, citing with approval Vasiljević Trial Judgment, para. 227.

${ }^{80}$ Brdanin Trial Judgment, para. 391, citing with approval Stakić Trial Judgment, para. 640, and other Judgments of the International Criminal Tribunal for Rwanda. 
identified in the jurisprudence of the ICTY. ${ }^{81}$ Pursuant to the first approach, which is formulated by the Krstic Trial Chamber, the mens rea of extermination, similar to the crime of murder, "consists of intention to kill or the intention to cause serious bodily injury to the victim which the perpetrator must have reasonably foreseen was likely to result in death." 82 Accordingly, the Krstić Judgment recognizes recklessness as a sufficient mens rea for the crime of extermination.

The Stakic Trial Chamber adopted a second approach ruling that the mens rea of extermination is either dolus directus or dolus eventualis. "It would be incompatible", as noted by the Stakić Trial Chamber, "with the character of the crime of extermination and with the system and construction of Article 5 if recklessness or gross negligence sufficed to hold an accused criminally responsible for such a crime." ${ }^{84}$ Thus, in order to sustain a conviction for extermination, the Prosecution has to demonstrate either that the accused has the conscious objective to kill persons on a massive scale or to create conditions of life that lead to the death of a large number of individuals (dolus directus); or the accused acted in the knowledge that annihilation of a mass of people would be the probable outcome and he reconciled himself to and made peace with it (dolus eventualis). Interestingly, this finding by Trial Chamber 1 clearly shows that mere common law recklessness is not equivalent to the continental law dolus eventualis. The latter requires a cognitive element of awareness and a volitional element of acceptance of the risk, whereas mere recklessness lacks such a volitional element.

The third approach has been articulated in the Vasiljević Trial Judgment which requires an additional element - the accused's awareness that his actions were part of a vast murderous enterprise in which a large number of individuals were systematically marked for killing or were killed:

81 In Kayishema, the Rwanda Tribunal found that the mens rea of extermination is that an accused through his act(s) or omission(s) must have intended the killing, or have been reckless, or grossly negligent as to whether the killing would result and that he must have been aware that his act or omission forms part of mass killing event, see Prosecutor v. Clément Kayishema and Obed Ruzindana, Case No. ICTR-95-1-T, Judgment, 21 May 1999, para. 144. It is to be noted that the Kayishema Judgment requires knowledge as to the circumstance element - the accused be aware that his act or omission formed part of mass killing attack. For more on the mens rea of extermination under the jurisprudence of the Rwanda Tribunal, see Mohamed Elewa Badar, 'Rethinking Mens Rea in the Jurisprudence of the International Criminal Tribunals for the Former Yugoslavia and Rwanda', in Olaoluwa Olusanya (ed), Rethinking International Criminal Law: The Substantive Part (The Hague: Europa Law Publishing, 2006) (forthcoming).

${ }^{82}$ Krstić Trial Judgment, para. 495.

${ }^{83}$ Stakić Trial Judgment, para. 642.

84 Ibid. 
"The offender must intend to kill, to inflict grievous bodily harm, or to inflict serious injury, in the reasonable knowledge that such act or omission is likely to cause death, or otherwise intends to participate in the elimination of a number of individuals, in the knowledge that his action is part of a vast murderous enterprise in which a large number of individuals are systematically marked for killing or killed." 85

Contrary to the Vasiljević position, the Blagojević, Brđanin, and Stakić Trial Chambers viewed the existence of a "vast scheme of collective murder" as mere evidence from which the accused's knowledge that his act was a part of a widespread or systematic attack against the civilian population may be inferred. According to these Trial Chambers, the "vast scheme of collective murder" is neither a legal ingredient element of the crime nor an additional layer of the mens rea for the commission of the crime. ${ }^{86}$ Recent judgement by the ICTY Appeals Chamber put an end to this long lasting debate ruling that "knowledge of 'a vast scheme of collective murder' is not an element required for extermination, a crime against humanity." ${ }^{87}$ In order to support its position, the Stakic Appeals Chamber relied on the finding of the ICTR in the Ntakirutimana Appeal Judgment:

"The ICTR Appeals Chamber has clearly stated that the actus reus of extermination is 'act of killing on a large scale.' The actus reus also includes 'subjecting a widespread number of people to conditions of living that would inevitably lead to death.' The mens rea required for extermination is that the accused intended, by his acts or omissions, either killing on a large scale, or the subjection of a widespread number of people, or the systematic subjection of a number of people, to conditions of living that would lead to their deaths." 88

It follows from the foregoing, that the mens rea of the crime of extermination requires "the intention to kill on a large scale or to systematically subject a large number of people to conditions of living that would lead to their deaths." ${ }^{\circ 9}$ This mens rea is a clear reflection of the actus reus of the crime. ${ }^{90}$

85 Vasiljević Trial Judgment, para. 229 (emphasis added). However, the Stakić Appeals Chamber noted that "the Vasiljević Trial Judgment did not include 'knowledge of a vast scheme of collective murder' in its summation of the elements of the crime of extermination." See Stakić Appeal Judgment, para. 258.

${ }^{86}$ Blagojević Trial Judgment, para. 576 endorsing the view of Brdanin Trial Judgment, para. 394; Stakić Trial Judgment, para. 640.

87 Stakić Appeal Judgment, para. 259.

88 Stakić Appeal Judgment, para. 259.

89 Stakić Appeal Judgment, para. 260.

90 Stakić Appeal Judgment, para. 260. The Stakić Appeal Chamber noted that there is no support in customary international law for the requirement of intent to kill a certain threshold of number of victims. 
Adopting, however implicitly, an element analysis approach, the Stakić Appeals Chamber found that there is no requirement of intent to kill a certain threshold number of victims simply because there is no numerical threshold established with respect to the actus reus of extermination. ${ }^{91}$

Thus, in the jurisprudence of the Yugoslavia Tribunal the mens rea of the offence of extermination is satisfied by either dolus directus or dolus eventualis - mere recklessness and gross negligence are excluded.

\section{Wilful Crimes}

Pursuant to Article 2 of the ICTY Statute, the term "wilful" or "willfully" is attached to three different types of offences, namely, wilful killing, wilfully causing great suffering or serious injury to body or health, and wilfully depriving a prisoner of war or civilian of the rights of fair and regular trial. In Article 3, the term is attached to "wilful damage". Through its jurisprudence, the ICTY has adopted the term "wilful" as the relevant mens rea standard with respect to offences that expressly contain that element.

\subsection{Wilful Killing ${ }^{92}$}

In the Celebici case, the Trial Chamber found that "the necessary intent, meaning mens rea, required to establish the crime of wilful killing and murder, as recognised in the 1949 Geneva Conventions, is present where there is demonstrated an intention on the part of the accused to kill, or inflict serious injury in reckless disregard of human life." ${ }^{93}$ In order to reach this conclusion, the Trial Chamber specifically relied on the International Committee

91 Stakić Appeal Judgment, para. 260.

${ }^{92}$ It is to be noted that under the jurisprudence of the ICTY the elements of this offence are the same for "murder" under Article 3 and 5. See in this regard Brdanin Trial Chamber, fn. 913: ' . . the constitutive requirements of murder and wilful killing under the different provision of the Statute are the same ...'; Čelebići Trial Judgement, para. 422: ‘. . . there can be no line drawn between "wilful killing" and "murder" which affects their content"; Krnojelac Trial Judgement, para. 323: "It is clear from the jurisprudence of the Tribunal that the elements of the offence of murder are the same under both Article 3 and Article 5 of the Statute".

93 Ćelebići Trial Judgement, para. 439. In paragraph 436 of the Čelebići Trial Chamber had this to say: "The Trial Chamber is mindful of the benefits of an approach which analyses the amount of risk taken by an accused that his action will result in death and considers whether that risk might be deemed excessive. Under this approach, all of the circumstances surrounding the infliction of harm and the resulting death of the victim are examined and the relevant question is whether it is apparent from these circumstances that the accused's actions were committed in a manner manifesting extreme indifference to the value of human life." 
for the Red Cross Commentary to the Additional Protocols (ICRC Commentary) which defines the adjective "wilfully" in the following terms:

"The accused must have acted consciously and with intent, i.e. with his mind on the act and its consequences, and willing them (criminal intent or malice aforethought); this encompasses concepts of wrongful intent or recklessness viz., the attitude of an agent who, without being certain of a particular result, accepts the possibility of it happening; on the other hand, ordinary negligence or lack of foresight is not covered, i.e. when a man acts without having his mind on the act or its consequence." 94

The above quoted definition of the term "wilfully", as viewed by the ICRC, has two important aspects. First, the term "wilfully" requires proof of the two components of the mental element, "knowledge" and "intent". The test is conjunctive; it has to be proved that the accused acted (a) consciously, and (b) with intent with regard to the material elements of the offence. The use of the phrase "willing them" within the ICRC definition assures that a volitive element must be established on the part of the defendant. The second aspect of the ICRC definition is the expansion of the term "wilfully" to encompass cases where the accused may well foresee death or serious injury as a possible result, and he accepts such a result. The inclusion of the verb "accept" within the definition of recklessness entails proof of a volitive element in addition to the element of "consciousness", no matter how weak the former element might be. This proposition is supported by both the Appeals Chamber and the Prosecution in the Blaškić case. In this case, the Prosecution submitted that the existence of a volitive component must be present in all forms of responsibility under Article 7(1) of the Statute..$^{95}$ The Blaškić Appeals Chamber asserted that "an awareness of a higher likelihood of risk and a volitional element must be incorporated in the legal standard." 96 The Chamber concluded that "[o]rdering with such awareness has to be regarded as accepting the crime." ${ }^{97}$ Furthermore, the findings rendered by the Celebici $i$ Trial Chambers on the law of "wilful killing" and "murder" support this proposition:

"While different legal systems utilise differing forms of classification of the mental element involved in the crime of murder, it is clear that some

94 ICRC Commentary on Additional Protocol I, Article 85, para. 3474, at 994 (emphasis added).

95 Prosecutor v. Tihomir Blaškić, Case No. IT-95-14-A, 14 June 2002, Prosecution's Respondent Appeal Brief, para. 5.28.

96 Blaškić Appeal Judgment, para. 41 (emphasis added).

${ }^{97}$ Ibid., para. 42 (emphasis added). 
form of intention is required. However, this intention may be inferred from the circumstances, whether one approaches the issue from the perspective of the foreseeability of death as a consequence of the acts of the accused, or the taking of an excessive risk which demonstrates recklessness." ${ }^{98}$

This finding by the Člebići Trial Chamber has two important aspects. First, it requires that some form of intention has to be established on the part of the accused in order to satisfy the threshold of wilful killing or murder. Second, the Trial Chamber, remarkably, distinguished between the intent required for these offences and the relevant circumstances from which this intent may be inferred. That is to say, foreseeability of death, or taking an excessive risk which resulted in death, is not in itself the mens rea required for the crime of wilful killing or murder, but it is sole evidence from which intent may be inferred. In Strugar, the Trial Chamber found that the necessary mental state of wilful killing and murder exits when "the accused knows that it is probable that his act or omission will cause death." ${ }^{\text {" Ho }}$ However, the Chamber noted that this formulation may prove to require amendment so that "knowledge that death or serious bodily harm is a probable consequence is sufficient to establish the necessary mens rea." 100

From a German perspective, this formulation by the ICRC may be likened to the "consent and approval theory" vis-à-vis the notion of dolus eventualis. This theory is applied by the German Courts, ${ }^{101}$ and is usually referred to as the "theory on consent and approval" (Einwilligungs - und Billigungstheorie). ${ }^{102}$ The majority of German legal scholars, who ascribe to this theory, are of the opinion that the offender must "seriously consider" the result's occurrence and must "accept the fact" that his conduct could fulfil the legal elements of the offence. ${ }^{103}$ Another way of putting the point is to say the offender must "reconcile himself" (sich abfinden) to the prohibited result. ${ }^{104}$

One might suggest that, by including the "acceptance" element within the concept of recklessness, the ICRC commentators crossed the boundaries of common law recklessness to adopt the conception of dolus eventualis in continental law countries. ${ }^{105}$ The ruling of the Trial Chamber in

98 Člebići Trial Judgement, para. 437 (emphasis added).

99 Strugar Trial Judgment, para. 236.

100 Strugar Rule 98 Trial Decision, para. 236.

101 BGHSt 36, 1; 44, 99; BGH NStZ (Neue Zeitschrift fuer Strafrecht, 1999) 507; BGH NStZ 2000, 583.

102 Johannes Wessels and Werner Beulke, Strafrecht Allgemeiner Teil (Heidelberg: Müller Verlag, 2002) 76.

${ }^{103}$ Claus Roxin, Strafrecht Allgemeiner Teil, (Muenchen: Beck'sche Verlagsbuchhandlung, 1997) 376.

104 Ibid. 
Stakić supports this proposition. In Stakic, the Trial Chamber finds that both a dolus directus and a dolus eventualis are sufficient to establish the requisite mental state of the crime of murder under Article 3 of the ICTY Statute and mutatis mutandis for wilful killing. According to the Stakic Judgment, the technical definition of dolus eventualis in German criminal law is the following:

"[I]f the actor engages in life-endangering behaviour, his killing becomes intentional if he "reconciles himself" or "makes peace" with the likelihood of death. Thus, if the killing is committed with "manifest indifference to the value of human life", even conduct of minimal risk can qualify as intentional homicide. Large scale killings that would be classified as reckless murder in the United States would meet the continental criteria of dolus eventualis." 106

In a recent case before the Yugoslavia Tribunal, Trial Chamber II ruled that in order to hold an individual criminally liable for murder under Article 3 of the ICTY Statute and mutatis mutandis for the crime of wilful killing it must be established that "[t]he [accused's] act or omission was committed with an intent to kill or inflict grievous bodily harm or serious injury, in the knowledge and with the acceptance that such act or omission was more likely than not to cause death." ${ }^{107}$ As the Tribunal put it more clearly:

"Intent to kill is required in order to fulfil the mens rea of murder. This includes proof of a mental state wherein the perpetrator foresees as more likely than not that the death of the victim could occur as a consequence of his act or omission, and he nevertheless accepts the risk. Negligence and gross negligence do not satisfy the mens rea requirement. Further, premeditation is not a mens rea requirement." 108

105 See Michael Bothe, 'War Crimes', in Antonio Cassese et al. (eds), The Rome Statute of the International Criminal Court: A Commentary (Oxford: Oxford University Press, 2001) 392: "[t]he term "wilful killing" was chosen by the drafters of the Geneva Conventions of 1949 without any clear idea as to what distinguishes killing which is wilful and which is not. ... A conduct can only be called wilful if the perpetrator acted intentionally or recklessly in relation to the death of the protected person."

106 Stakić Trial Judgment, para. 587.

107 Orić Trial Judgment, paras. 346-347 (emphasis added). In paragraph 345 of its Judgment, the Orić Trial Chamber asserted that: "The definition of murder as a violation of the laws or customs of war is now settled in the jurisprudence of this Tribunal and of the ICTR. The elements defining murder under Article 3 of the Statute are identical to those required for 'wilful killing' as a grave breach of the 1949 Geneva Conventions under Article 2 of the Statute and murder as a crime against humanity under Article 5 of the Statute.”

${ }_{108}$ Orić Trial Judgment, para. 348, (footnotes omitted). 
Interestingly, the Orić Trial Chamber asserted that individual criminal responsibility for serious crimes over which the ICTY has jurisdiction requires intention, ${ }^{109}$ and agreed with the Defence submission that intent does not include recklessness. ${ }^{110}$ In the words of the Orić Judgment, "intention contains (1) a cognitive element of knowledge and (2) a volitional element of acceptance. ..."111 Accordingly, mere knowledge on the part of the accused is not sufficient to trigger the criminal liability for individuals for serious violations of international humanitarian law.

A further point that deserves particular mention is that the jurisprudence of the Yugoslavia Tribunal, in establishing the requisite mens rea for "wilful killing", focused solely on the state of mind of the accused vis-à-vis the consequence of his conduct, leaving aside the mens rea required as to the circumstance element - the factual element that renders a particular individual a protected person. ${ }^{112}$ This element is considered under the jurisprudence of the ICTY as a factual element and not a jurisdictional one. In Čelebici $i$, the Appeals Chamber noted that the definition of wilful killing under Article 2 contains a materially distinct element not present in the definition of murder under the other articles of the Statute: namely, the requirement that the victim be a protected person. ${ }^{113}$ Hence, the question as to whether the Prosecution, in order to sustain a conviction for wilful killing under Article 2 of the ICTY Statute, had to prove that the defendant knew that his victim was a protected person is left unresolved under the jurisprudence of the Yugoslavia Tribunal. One might conclude that an accused, charged with "wilful killing" under Article 2, must be proved to have been aware of the fact that the victim was a protected person (circumstantial element), in addition to the mental state required with regard to the result element (dolus directus or dolus eventualis). In support of this conclusion, one might refer to the adjudication of Trial Chamber I in the Galić case where it stated, concerning the crime of attacks on civilians set forth in Article 51 of Additional Protocol I and Article 13 of Additional Protocol II and punishable under Article 3 of the ICTY Statute:

"For the mens rea recognized by Additional Protocol I to be proven, the Prosecution must show that the perpetrator was aware or should have

109 Orić Trial Judgment, para. 279.

110 Orić Trial Judgment, fn. 1020.

111 Orić Trial Judgment, para. 279 (numbers added).

112 The chapeau of Article 2 of the ICTY read as follows: 'The International Tribunal shall have the power to prosecute persons committed . . grave breaches of the Geneva Conventions of 12 August 1949, namely the following acts against persons or property protected under the provisions of the relevant Geneva Convention.' "Protected persons" are defined in Article 4(1) of the fourth Geneva Convention as those "in the hands of a Party to the conflict or Occupying Power of which they are not nationals."

113 Čelebići Appeal Judgement, paras. 413, 423. 
been aware of the civilian status of the persons attacked. In case of doubt as to the status of a person, that person shall be considered to be a civilian. However, in such cases, the Prosecution must show that in the given circumstances a reasonable person could not have believed that the individual he or she attacked was a combatant." 114

This finding by the Galic Trial Chamber is cited with approval in the Halilovic case, where the Trial Chamber asserted that "the mens rea of the perpetrator of murder must encompass the fact that the victims were persons taking no active part in the hostilities." ${ }^{115}$ By analogy, to establish criminal responsibility for wilful killing under Article 2 of the ICTY Statute, the Prosecution must prove that the defendant was aware or should have been aware of the status of the persons attacked. The same position was endorsed by Professors Roger Clark and William Schabas, "the combatant who kills a protected person in error, believing that person to be a combatant and a lawful target, ought to have a defence of mistake of fact." 116

\subsection{Wilfully Causing Great Suffering or Serious Injury to Body or Health}

Article 2(c) of the Statute embodies the grave breach of willfully causing great suffering or serious injury to body or health. ${ }^{117}$ The Ćelebići Trial Judgement defined this offence as "an act or omission that is intentional, being an act which, judged objectively, is deliberate and not accidental, which causes serious mental or physical suffering or injury." 118 It is distinguished from torture primarily on the basis that the alleged acts or omissions need not be committed for a prohibited purpose such as is required for the offence of torture. ${ }^{119}$ Hence, both torture and the crime of willfully causing great suffering must be committed intentionally. For the latter offence, the perpetrator must have intended to act in a way which, in the normal course

${ }^{114}$ Galić Trial Judgment, para. 55. This finding by Galić Trial Chamber was cited with approval in Halilović Trial Judgment, para. 36.

115 Halilović Trial Judgment, para. 36; Strugar Trial Judgment, para. 236; Naletilić Trial Judgment, para. 248.

116 William A. Schabas, 'Mens Rea and the International Criminal Tribunal for the Former Yugoslavia', 37 New England Law Review (2002-2003) 1015, 1021-2, citing Roger S. Clark, 'The Mental Element in International Criminal Law: The Rome Statute of the International Criminal Court and the Element of Offences', 12 Criminal Law Forum (2001) 291, 330-31.

${ }^{117}$ See Articles 50, 51, 130, and 147 of the 1949 Geneva Conventions I, II, III and IV respectively.

${ }_{118}$ Čelebići Trial Judgement, para. 511 (emphasis added).

${ }^{119}$ Ibid., para. 442. 
of events, would cause great suffering or serious injury to body or health. ${ }^{120}$ Similarly, in Kordic, the Trial Chamber found that the crime of "wilfully causing great suffering" constitutes "an intentional act or omission which causes serious mental or physical suffering or injury, provided the requisite level of suffering or injury can be proven." 121 In Blaškić, the defence submitted that the requisite mens rea of this offence "is the specific intent to cause the victim to suffer such treatment." 122 As with "inhumane treatment", punishable under Article 2(b) of the ICTY Statute, the defence argued that the mens rea requirement for "wilfully causing great suffering" should be distinguished from the mens rea applicable to a charge of "wilful killing" under Article 2(a). ${ }^{123}$ It contends that, in order to sustain a conviction for "wilfully causing great suffering or serious injury to body or health", the Prosecution must prove that the defendants or his subordinates intended that result, and, in addition that the defendant or his subordinates acted because he or they meant for the victim to suffer. ${ }^{124}$

In light of the foregoing, the offence of "wilfully causing great suffering" requires a direct intent. That is to say dolus eventualis or indirect intent is not a sufficient mens rea for this offence. The above analysis of the ICTY judgments evidenced that the term "wilfully" is given two different degrees of mens rea. Where the term is attached to "killing", it encompass both mental states direct and indirect intent (dolus eventualis), whereas in the case of "causing great suffering or serious injury" it means intent in the strict sense. Professor Schabas observed that "[i]f the term "killing" were to stand alone, without the adjective "wilful," it might be argued that the crime might also include non-intentional forms of homicide." 125

\subsection{Destruction or Wilful Damage to Institutions Dedicated to Religion or Education}

This offence encompasses violations of customary rules of international humanitarian law concerning the protection of certain types of property in

${ }^{120}$ In the Limaj case, the Trial Chamber defined the mental state of torture as requiring direct intent, Limaj Trial Judgment, para. 238.

${ }^{121}$ Kordić Trial Judgement, para. 245.

${ }^{122}$ Prosecutor v. Blaškić, Case No. IT-95-14-T, Defence Final Trial Brief, 22 July 1999, at $57-8$.

123 Ibid.

${ }^{124}$ Prosecutor v. Blaškić, Case No. IT-95-14-T, Defence Final Trial Brief, 22 July 1999, at 57-8 (on file with the author).

${ }^{125}$ Schabas, Mens Rea and the International Criminal Tribunal for the Former Yugoslavia, supra note 118 , at 1020 . 
war. ${ }^{126}$ Article 3(d) of the ICTY Statute takes its expression from the corresponding conventional rule found in Article 27 of the Hague regulations of 1907, Article 4 of the Hague Convention of 1954, and Article 53 of Additional Protocol II. ${ }^{127}$ In Strugar, the Trial Chamber noted that, while these provisions prohibit acts of hostility directed against cultural property, "Article 3(d) of the Statute explicitly criminalizes only those acts which result in damage to, or destruction of, such property." 128 According to the Strugar Trial Chamber, the actual damage or destruction occurring as a result of an act directed against this property is an ingredient element in this

\section{Article 3(d) ICTY Statute reads:}

The International Tribunal shall have the power to prosecute persons violating the laws or customs of war. Such violations shall include, but not limited to:

(d) seizure of, destruction or wilful damage done to institutions dedicated to religion, charity and education, the arts and sciences, historic monuments and works or art and science;

127 Article 27 of the Hague Regulations of 1907 reads:

In sieges and bombardments all necessary steps must be taken to spare, as far as possible, buildings dedicated to religion, art, science, or charitable, purposes, historic monuments, hospitals, and places where the sick and wounded are collected, provided they are not being used at the time for military purposes.

Article 4 of the Hague Convention of 1954 requires the States Parties to the Convention to:

1. [...] respect cultural property situated within their own territory as well as within the territory of other High Contracting Parties by refraining of any use of the property and its immediate surroundings or of the appliances in use for its protection for purposes which are likely to expose it to destruction or damage in the event of armed conflict; and by refraining from any act of hostility directed against such property.

2. The obligations mentioned in paragraph 1 of the present Article may be viewed only when military necessity imperatively requires such a waiver.

4. They shall refrain from any act directed by way of reprisals against cultural property.

Article 53 of Additional Protocol II reads:

Without prejudice to the Provisions of the Hague Convention for the Protection of Cultural Property in the Event of Armed Conflict of 1954, and of other relevant international instruments, it is prohibited:

(a) to commit any acts of hostility directed against the historic monuments, works of art or places of worship which constitute the cultural or spiritual heritage of peoples;

(b) to use such objects in support of the military effort;

(c) to make such objects the object of reprisals.

${ }_{128}$ Strugar Trial Judgment, para. 308. 
offence. ${ }^{129}$ Despite the plural used in Article 3(d), it would be sufficient for the purpose of individual criminal liability that one institution protected under this provision - and, by analogy, one monument or one piece of work - is seized, destroyed or damaged. ${ }^{130}$

With respect to the mens rea requisite for the offence of destruction or devastation of property under Article 3(d), the jurisprudence of the ICTY consistently maintains that the destruction or damage must have been committed wilfully and that the accused must be shown to have intended, by his acts or conduct, to cause the destruction or damage to the property in question. ${ }^{131}$ That is to say, and as understood by the ICTY Trial Chambers, the mens rea requirement for this offence is dolus directus, or direct intent. ${ }^{132}$ However, the Bardnin Trial Chamber disagrees with previous judgments' restriction of the mens rea threshold of this offence for the following reason:

"[A]s religious institutions enjoy the minimum protection afforded to civilian objects the mens rea requisite for this offence should be equivalent to that required for the destruction or devastation of property under Article 3(b)."'133

Therefore, according to the Bardnin Trial Chamber, the mens rea required for "the destruction or wilful damage done to institutions dedicated to religion must have been either perpetrated intentionally, with the knowledge and will of the proscribed result or in reckless disregard of the substantial likelihood of the destruction or damage." 134 It was further questioned by the Strugar Trial Chamber "whether indirect intent ought also to be an acceptable form of mens rea for this crime." 135 Thus, to establish criminal responsibility for an offence punishable under Article 3(d) of the ICTY Statute, the prosecution must demonstrate that the perpetrator's "will" was directed towards the accomplishment of the result in question (actual damage or destruction of the property). The question as to whether indirect intent is a

129 Ibid.

${ }^{130}$ In the Naletilic case, the Prosecution charged the accused for allegedly ordering the destruction of the mosque of Sovići (Count 22: Seizure, destruction or wilful damage done to institutions dedicated to religion).

131 Strugar Trial Judgment, para. 311; Blaškić Trial Judgment, para. 185: "The damage or destruction must have been committed intentionally"; Naletilić Trial Judgment, paras. 603-4: "[T] he perpetrator acted with intent to destroy the property"; Kordić Trial Judgment, para. 361.

132 Strugar Trial Judgment, para. 299.

133 Brdanin Trial Judgment, para. 599.

134 Ibid.

135 Strugar Trial Judgment, para. 311. 
sufficient mens rea standard to trigger the criminal responsibility of this offence is still unclear under the jurisprudence of the Yugoslavia Tribunal. ${ }^{136}$

To conclude, "wilfulness" for the purpose of the ICTY Statute requires the Prosecution to prove beyond reasonable doubt that the perpetrator when he so acted had one or the other of the following mental states: (i) the perpetrator had the intention to bring about the result; or (ii) the perpetrator acted in reckless disregard of the likelihood of the consequence in question.

\section{Wanton Crimes}

\subsection{Unlawful and Wanton Extensive Destruction and Appropriation of Property}

Article 2(d) of the Statute sanctions "extensive destruction and appropriation of property when it is not justified by military necessity and is carried out unlawfully and wantonly" as a grave breach of the Geneva Conventions of 1949. ${ }^{137}$ This provision combines two separate acts: (i) the destruction of property; and (ii) the appropriation of property. ${ }^{138}$ The plain meaning of Article 2(d) requires the destruction or appropriation to be extensive. However, one might well raise the question as to whether destruction or appropriation committed on a small scale fulfils the requirement of Article 2(d) in conjunction with Article 1 of the Statute which states that the Tribunal "shall have the power to prosecute persons responsible for serious violations of international humanitarian law." Addressing this point, the Naletelić Trial

136 One scholar has noted that, according to the Naletilić, Blaškić, and Kordić Trial Chambers, negligent damage, even if gross or reckless, would not come within the realm of the prohibition. The author contends that 'none of these Trial Chambers offered any authority to support its conclusion that, under customary international law, the mens rea for that offence was so defined or so restricted.' See Mettraux, International Crimes, supra note 31, p. 95, fn. 21 and the above text.

137 Article 2(d) of the ICTY Statute is based on Article 147 of Geneva Convention IV which sanctions as a grave breach the extensive destruction and appropriation of property protected by the Convention, not justified by military necessity and carried out unlawfully and wantonly. See Articles 50, 51, and 130 of the 1949 Geneva Conventions I, II, and III respectively.

138 Brdanin Trial Judgment, para. 584. In Naletelic, the Trial Chamber found that "two types of property are protected under the grave breach regime: (i) property, regardless of whether or not it is in occupied territory, that carries general protection under the Geneva Conventions of 1949, such as civilian hospitals, medical aircraft and ambulances; and (ii) property protected under Article 53 of the Geneva Conventions IV, which is real or personal property situated in occupied territory when the destruction was not absolutely necessary by military operations.", ibid, para. 575 (footnotes omitted). 
Chamber ruled that "a single act may, in exceptional circumstances, be interpreted as fulfilling the requirement of extensiveness, as for instance the bombing of a hospital." 139

With regard to the mens rea requirement for destruction of property, the Barđnin, Naletelić, and Kordić Trial Chambers agreed that, in order to uphold a conviction for this offence, the prosecution has to prove that the perpetrator had the intent to destroy the protected property or had acted in reckless disregard of the likelihood of its destruction. ${ }^{140}$

As far as the mens rea of appropriation of property is concerned, the Bardnin Trial Chamber held that "the perpetrator must have acted intentionally, with knowledge and will of the proscribed result." ${ }^{141}$ In support of this conclusion, the Bardnin Trial Chamber endorsed the findings of the Naletelic Judgment on the law of "plunder" where this offence, as sanctioned under Article 3(e) of the Statute, has been defined in paragraph 612 as "willful and unlawful appropriation of property." "142 This paragraph has a footnote which reads as follows:

"The Čelebici $i$ Trial Judgment ... does not explicitly discuss the subjective element of plunder; however, it mentions looting by soldiers for their private gain and systematic economic exploitation of occupied territory, both, clearly implying intent, para. 590. The Blaškić Trial Judgment, para. 184 asserts that plunder is "wanton appropriation", seemingly referring to the indifference to consequences for the victims rather than to a specific mens rea requirement. The Kordić Trial Judgment, para. 394, requires that the property be acquired "willfully". The Jelesić Trial Judgment, para. 48, requires appropriation to be "fraudulent", motivated by greed." 143

Accordingly, the Naletelic Trial Chamber concluded that "intent in the appropriation of property is the necessary subjective element of plunder."144

139 Naletelić Trial Judgment, para. 576; Brdanin Trial Judgment, para. 587; Blaškić Trial Judgment, para. 157.

${ }^{140}$ Brdanin Trial Judgment, para. 589; Naletelić Trial Judgment, para. 577; Kordić Trial Judgment para. 341.

${ }^{141}$ Brdanin Trial Judgment, para. 590 (emphasis added).

142 Naletilić Trial Judgment, para. 612.

143 Naletilić Trial Judgment, fn. 1498, p. 208.

144 Ibid., (emphasis added). Most notably, other grave breaches which do not include, in their definition, the words "wilful", "wilfully" or "wantonly" must also be committed with intent. In Čelebići, the Trial Chamber found that grave breach of inhumane treatment consists of "an intentional act or omission, that is an act which, judged objectively, is deliberate and not accidental, which causes serious mental harm or physical suffering or injury or constitutes a serious attack on human dignity." Čelebići Trial Judgment, para. 348. I am indebted to Professor Schabas for this observation, see Schabas, Mens Rea and the International Criminal Tribunal for the Former Yugoslavia, supra note 118, at 1021. 


\subsection{Wanton Destruction of Cities, Towns or Villages, or Devastation not Justified by Military Necessity}

Wanton destruction of cities, towns or villages, or devastation not justified by military necessity are two separate crimes punishable as a violation of the laws or customs of war under Article 3(b) of the Statute. ${ }^{145}$ The elements of the crime of "wanton destruction not justified by military necessity" were identified by the Trial and Appeals Chamber in the Kordic case in the following terms:

"(i) the destruction of property occurs on a large scale;

(ii) the destruction is not justified by military necessity; and

(iii) the perpetrator acted with the intent to destroy the property in question or in reckless disregard of the likelihood of its destruction." ${ }^{146}$

The mens rea required for the destruction or devastation of property under Article 3(b) was subject to a different understanding by the Yugoslavia Tribunal. According to the Blaškić Judgment, "the devastation must have been perpetrated intentionally or have been the foreseeable consequence of the acts of the accused." 147 This approach was subject to slight modification by the Kordić, Naletilić, Stakić Trial Chambers in which the mens rea of the crime of wanton destruction was defined as "the intent to destroy the property in question or reckless disregard of the likelihood of its destruction." 148 In Strugar, the Trial Chamber used different terms with regard to the mens rea requisite for the offence in question. The Chamber ruled that "the mens rea requirement for a crime under Article 3(b) is met when the perpetrator acted with either direct or indirect intent, the latter requiring knowledge that devastation was a probable consequence of his acts." 149 However, one might well raise the question as to whether knowledge that the act will probably

145 Strugar Trial Judgment, para. 290. Whereas in the Kordić and Naletilic cases the accused were indicted with the offence of "wanton destruction not justified by military necessity", in Blaškić and Strugar, the accused were indicted with the offence of "devastation not justified by military necessity". In Brdanin, however, the prosecution has charged the accused with both offences "wanton destruction of cities, towns and villages, or devastation not justified by military necessity."

${ }^{146}$ Kordić Trial Judgment, para. 346; Kordić Appeals Judgment, para. 74. See also Naletilić Trial Judgment, para. 579; Hadžihasanović Rule 98 Trial Decision, para. 107; Stakić Trial Judgment, para. 761. In Strugar, the Trial Chamber applied this definition to the crime of devastation with appropriate adaptations to reflect "devastation", for the crime of "devastation not justified by military necessity",

147 Blaškić Trial Judgment, para. 183 (emphasis added).

148 Kordić Trial Judgment, para. 346; Naletilić Trial Judgment, para. 579 (emphasis added). See also Koridć Appeal Judgment, para. 74.

149 Strugar Trial Judgment, paras. 296-7. 
cause the proscribed result is the same mens rea standard as foresight of the result of the act. Addressing this point, the Naletilic Trial Chamber found that there is no substantial difference between the two standards; "reckless disregard" is equal to "foreseeability of the consequences of the conduct and acceptance of the results as its very likely consequence."150

\section{General Remarks and Conclusion}

The present study reveals the evolutionary developments of the law of mens rea in the jurisprudence of the ICTY. Through its jurisprudence, the Yugoslavia Tribunal has employed different mens rea terms and maxims in order to maintain the culpability levels required for serious violations of international humanitarian law. The first types of culpability terms used by the ICTY are 'specific intent' or 'dolus specialis', both terms seem to be used interchangeably. It is evident from the case law of the ICTY that these terms are attributed to particular classes of crimes which require a surplus of intent, a particular intent to achieve some further consequence beyond the result that constitutes the actus reus of the offence in question. As noted by Professor Cassese:

"International rules may require a special intent (dolus specialis, dol aggravé) for particular classes of crimes. There is such special intent when an international rule, in addition to requiring the intent to bring about a certain result by undertaking certain conduct (for example, death by killing), also requires that the agent pursue a specific goal that goes beyond the result of his conduct, with the consequence that attainment of such goal is not necessary for the crime to be consummated." 151

Furthermore, the ICTY has assigned, for this category of crimes, a higher degree of mens rea which is equated to "purpose", a culpability level known to both common and continental legal systems. ${ }^{152}$

150 Naletilić Trial Judgment, fn. 1440.

151 Antonio Cassese, International Criminal Law, (Oxford: Oxford University Press, 2003) 167-8.

152 This higher degree of mens rea is known in German criminal law as Absicht. It is the gravest aspect of culpability in which the volitive part dominates. In German law, it is generally assumed that an offender acts with Absicht if he desires to bring about the result. In this type of intent, the perpetrator's "will" is directed finally towards the accomplishment of that result. Absicht is also defined as a "purpose-bound will". In the Model penal Code, however, the term "purposely" as employed in $\S 2.02(2)(a)$ of the Model Code has two different meanings, depending upon whether the material element of the offence in question is related to a conduct or result, on the one hand, or to attendant circumstances, on the other. With respect to conduct or result, a person acts "purposely" if it is his "conscious object to engage in conduct of that nature or to cause such a result." 
The second culpability term used by the Yugoslavia Tribunal is direct intent or dolus directus. The ICTY attributed this level of culpability for particular crimes such as rape and outrages upon personal dignity. The terms "intentional", "intentionally" and "deliberately" are used interchangeably by the ICTY in order to signify this culpability level. In most cases where the Tribunal required intent (in the strict sense) as a requisite mens rea for a particular crime under its jurisdiction, this degree of intent is not attributed to all the material elements of the crime in question (conduct, circumstance, and consequence). Taking the crime of outrages upon personal dignity as an example, the ICTY assigned a higher degree of mens rea "intentionally" with regard to the "nature of the conduct" whereas, with regard to "result element" it assigned a culpable mental state of recklessness as opposed to actual knowledge.

The third level of culpability recognized by the Tribunal is indirect intent. Through its judgments, the Tribunal refers to this degree of mens rea as advertant recklessness or dolus eventualis. Both terms are used interchangeably by the ICTY to refer to a state of mind where "the person foresees that his action is likely to produce its prohibited consequences, and nevertheless takes the risk of so acting." 153 Both dolus eventualis or advertant recklessness as understood by the ICTY require a "risk assessment", i.e. the appreciation of the likeliness of the result which excludes mere criminal negligence.

The present study reveals that, in the jurisprudence of the ICTY, the concept of recklessness - just as with the continental law dolus eventualis requires some sort of acceptance on the part of the accused of the risk that he has recognized and some sort of decision to act in spite of that risk. This decision to "act anyway" is equivalent to the "manifest indifference" towards and the "complete disregard" for the outcome of the conduct. However, the question of the degree of foresight or the assessment of the probability of the risk remains unclear.

Other offences in the subject matter jurisdiction of the ICTY contain, in their language, a mental element, namely, "wilful" and "wanton". The question as to whether direct or indirect intent is a sufficient mens rea standard to trigger the criminal responsibility for offences where the adverb "wanton" or "wilful" is attached is still not yet settled in the jurisprudence of the Yugoslavia Tribunal.

The absence of a general provision on the mental element in the ICTY Statute left the door open to the jurisprudence of this Tribunal to provide, on an ex post facto basis, the elements of criminal responsibility. ${ }^{154}$ Thus, everything from

153 Cassese, International Criminal Law, p. 168 (emphasis in the original).

154 M. Cherif Bassiouni, Introduction to International Criminal Law, (New York: Transnational Publishers: 2003) 259-260. 
defining the required mens rea to whether mistake of law or fact can be a defence was left to the judicial determination. By the standards of many legal systems, such a process violates the principles of legality, nullum crimen sine lege. ${ }^{155}$ As remarkably observed by Professor Bassiouni:

"The judicial process in the cases of the IMT, IMTFE, ICTY and ICTR was, for all practical purposes, an intuitive judicial method of ascertaining and applying what they believe to be part of general principles of law. The term intuitive means that the judges in a given case acting on the basis of their knowledge and individual research, reach a conclusion without following a method recognized in comparative criminal law technique. The haphazard nature of the process, however, did not necessarily exclude the reaching of correct outcomes which are consonant with what a proper methodology would have reached. But that also meant that the process was unpredictable and the outcomes not always consistent with a given theory of law. The absence of pre-existing norms of a general part also meant that the prosecution was frequently uncertain as to what it had to prove, and the defence equally uncertain as to its ability to challenge it, or advance argument for exoneration."156

155 Ibid. Contra see William A. Schabas, 'Mens Rea and the International Criminal Tribunal for the Former Yugoslavia', 37 New England Law Review (2002-2003) 1015, 1025: “. . . although not required within the text of the ICTY Statute [a general provision on the mental element], in contrast with the Rome Statute, the judges of the ICTY have treated mens rea as an element of all of the offences within the Tribunal's subject matter jurisdiction.... Incidentally, this would suggest that article 30 of the Rome Statute is not only confusing and ambiguous, it is also superfluous, and that judges of the International Criminal Court, like their colleagues at the ICTY, would easily have understood the mental element of crimes without them having to be told."

${ }^{156}$ Bassiouni, Introduction to International Criminal Law, supra note 155. 
Copyright of International Criminal Law Review is the property of Martinus Nijhoff and its content may not be copied or emailed to multiple sites or posted to a listserv without the copyright holder's express written permission. However, users may print, download, or email articles for individual use. 